\title{
The Effect of Gamma Cobalt-60 Ray Irradiation on Cultivar Growth in Taro White (Xhanthosoma Sagittifolium L.)
}

\author{
Nurul Fadli ${ }^{1}$, Zulfadly Syarif ${ }^{2}$, Benni Satria ${ }^{3}$, Nasrez Akhir ${ }^{4}$ \\ ${ }^{1}$ Department of Agronomy, Faculty of Agriculture, Andalas University, Padang - West Sumatera, INDONESIA \\ Email: Fadlinuru1440@yahoo.com \\ ${ }^{2}$ Department of Agrotechnology Faculty of Agriculture, Andalas University, Padang - West Sumatera, INDONESIA \\ Email: Syarif_zulfadly@yahoo.com \\ ${ }^{3}$ Department of Agrotechnology Faculty of Agriculture, Andalas University,Padang West Sumatera INDONESIA \\ Email: Benni bd@yahoo.com \\ ${ }^{4}$ Department of Agrotechnology Faculty of Agriculture, Andalas University,Padang West Sumatera INDONESIA \\ Email: Nasrezaakhir@gmail.com
}

\begin{abstract}
The purpose of this study was to determine the effect of cobalt-60 gamma ray irradiation which could expand the genetic security of white taro cultivars (Xhanthosoma sagittifolium $(L)$ ). This research has been carried out in June - September 2018 at the Center for Isotope and Radiation Applications, the National Atomic Agency (BATAN) Jakarta, and the Experimental Garden of the Faculty of Agriculture, Andalas University, Padang. Experimental method of gamma cobalt -60 ray irradiation with 0 gray dose; 30; 60; 90; and 120 gray, observations with Single Plant using Student test t test at level 5\%. The results showed that the Ld 50 (Lethal dose 50) value, at the level of Gammacell 220 light irradiation (Cobalt-60) occurred in 60 gray, leaf color variation only occurred at irradiation rates of 30 and 90 gray while for plant heights occur at all levels of irradiation.
\end{abstract}

Keywords-Taro plants, growth, radiation.

\section{INTRODUCTION}

Along with the development of the population, problems arise in the limitations of food production (staple food in Indonesia is rice). It is not impossible that in the future there will be an imbalance between population growth which is getting faster and requires the consumption of large staple foods, but limited food production. Therefore, it is necessary to diversify consumption of food other than staple foods with other food products from agricultural commodities other than rice (Hafsah et al, 2014).

Carbohydrate needs from year to year continue to increase, serelia carbohydrate supply is not enough, so the role of carbohydrate-producing plants that have a strategic role can be used as a source of local foodstuffs (Arifin, 2015). In Permenhut P.35 / 2007 concerning Non-Timber
Forest Products / NTFPs, taro food crops are grouped into pati-patian plants which state that tubers such as taro are very potential to meet food needs because they have a large enough taro production potential (Sudomo and Aditya, 2014) Taro tuber is one of the tubers that has important prospects and has high economic value compared to other types of tubers. Judging from its nutritional content, taro tubers include healthy and safe food commodities, the level of safety lies in the low carbohydrate content $(27.25 \%)$, reducing sugar $(0.87 \%)$ and starch content (24.11\%) (Rudyatmi and Enni, 2014) Taro has a lower glycemic index (GI) compared to rice, potatoes and other carbohydrate sources. The glycemic index is the level of food according to its effect on blood sugar levels. In other words the glycemic index is the blood glucose response to food. The glycemic index is useful for determining the blood glucose response to the type and amount of food consumed, besides that taro is one of the functional food crops because in taro tubers contain bioactive ingredients that are efficacious for health, but the use of taro tubers cannot be used directly by society because of the length of the vegetative phase (Sundari et al, 2014).

Mutation induction using irradiation produces the most mutants (around 75\%) when compared to using other treatments such as chemical mutagens. Gamma rays are short electromagnetic waves with high energy interacting with atoms or molecules to produce free radicals in cells. These free radicals will induce mutations in the plant because they will produce cellular damage or an important influence on plant cell components (Kovacs and Keresztes, 2002). The dose of radiation given to get mutants depends on the type of plant, the phase of growth, size, hardness, and material to be transferred. The 
results showed that gamma ray radiation with a dose of $100 \mathrm{~Gy}$ on chrysanthemum can change the color of the white flower of the purple edge to yellow, while the maximum dose for grains and cereals is 5 Gy (Gehring, 1985).

Given the importance of food diversification and food security it is time to use tubers that can support daily food needs, the content of taro tubers can be a source of carbohydrate substitute for rice which is rich in nutrients, low GI and low in calcium oxalate. Taro consumption can also prevent the risk of heart problems and high blood pressure. In addition, taro also increases alkaline levels in the mouth so that it can make teeth stronger (Bryan et al., 2014).In this study will try to treat the mutation method by physically mutating cobalt-60 in taro genus plant tubers (Xhanthosoma sagittofolium (L)) which is expected to damage the genetic DNA structure of taro plants that encode the production of calcium oxalate.

The purpose of this study was to determine the effect of cobalt-60 gamma ray irradiation capable of expanding the genetic security of white taro cultivars (Xhanthosoma sagittifoilm (L)).

\section{MATERIALS AND METHODS}

This research was carried out in June - September 2018 gamma ray irradiation treatment was carried out at the Center for Isotope and Radiation Applications, National Atomic Body (BATAN) Jakarta. Tuber nursery and moving the field were carried out at the Agricultural Faculty Experimental Garden of Andalas University, Padang.

This research is using experimental method. Treatment of gamma cobalt-60 irradiation with 0 gray doses; 30; 60; 90; and 120 gray, each gray dose contained 40 samples of taro tubers, bringing the total to 200 tubers. Observation method that is carried out is Single Plant. The test uses the Student test $\mathrm{t}$ test at the 5\% level (Little and Jackson, 1978). Sampling of taro plants derived from taro farmers in Nagari Limo Kaum Tanah Datar District with the criteria of shoots buds have appeared buds \pm 2 $\mathrm{cm}$ long and not attacked by pests and diseases.

\section{RESULTS AND DISCUSSIONS}

\section{LD 50 (Lethal dose 50)}

The Ld 50 (lethal dose 50) value, which is the dose level (gray) which causes the death of $50 \%$ of the irradiated plant population. Optimal graying in mutation induction that causes diversity and produces the most mutants usually occurs around $\mathrm{Ld} \mathrm{50.} \mathrm{Calculation} \mathrm{of} \mathrm{Ld}$ 50 values uses the Thoms on and Weil (1952) method. Ld 50 (lethal dose 50) data can be seen in table 1.

Based on observations in the field after irradiation of tubers with Gammacell 220 light (Cobalt-60), there was a difference in the growth rate of tubers in some gray, at 0 gray showed the tubers had grown and began to remove leaves at the age of 1 MST while 30 gray, 60 gray, 90 gray and 120 gray show bulbs grow and start removing leaf strands at the age of 2 MST. Gamma ray irradiation that causes random mutations results in physiological damage in the metabolism of cell development, so that its growth potential can be faster or slower (Aisyah, 2013).

The optimal gray dose in mutation induction that causes diversity and produces the most mutants usually

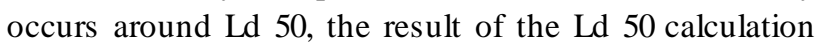
using the Thomson and Weil (1952) method. shows that the approach is 60 gray $54.98 \%$ while the highest is 120 gray $123.87 \%$. Aisyah (2006) revealed that generally the desired mutation would lie in the $\mathrm{Ld} 50$ dose range.

The administration of gamma ray irradiation on taro tubers is very influential on the growth of taro tubers indicating that the increase in irradiation gray decreases the rate of growth of taro tubers. This indicates that high gamma ray irradiation can inhibit the growth rate of taro tubers. This is in accordance with research conducted by Pramono (2011), which uses gamma rays and is applied to iles-iles plants resulting in plant death. Changes in phenotypes resulting from mutations vary, ranging from minor changes that are only detected by biochemical analysis methods to the drastic changes that occur in essential metabolic processes that cause the death of cells or organisms.

In some tubers that do not grow, the tuber skin conditions like burning, the buds grow brown, then the decay occurs in the eyes of shoots, besides the condition of the bulbs is soft when the tuber is cut open and the color of the reddish tuber (browning) looks. Somatic cell death due to irradiation can occur directly and indirectly. Direct consequences, in addition to the degradation of enzymes that play a role in IAA biosynthesis, also occur due to damage to DNA and chromosomes whose damage will increase along with the increase in irradiation doses (Kim et al., 2004). The appearance of taro plants after Gammacell 220 cobalt- (60) ray irradiation can be seen in Figure 1 below.

Ld50 value can be obtained by knowing the response pattern of plant growth power to various irradiation doses. Figure 1 shows the various responses to the growing power of taro plants.

The deterministic effect arises when the gray received by the plant is above the threshold gray and generally arises shortly after irradiation. The severity of the deterministic effect will increase if the received gray is greater than the threshold gray. Ld 50 in the above tubers is generally high, this indicates that the tubers have low radiosensitivity. This is suspected because the water content in the tuber is very high. The more levels of oxygen and water molecules $(\mathrm{H} 2 \mathrm{O})$ in irradiated material, the more free radicals will be formed so that plants 
become more sensitive (Herison, et al., 2008). Ionization due to irradiation can cause the grouping of molecules along the path of the ion left behind due to irradiation which can cause gene mutation or chromosomal dredging (Aisyah, 2006). Indirect effects, namely the presence of toxic effects from free radicals $\mathrm{H} 2 \mathrm{O} 2$ and $\mathrm{OH}$ - which are produced from water radiolysis (Soeranto, 2003). The most irradiated material is water which then decomposes into $\mathrm{H} 2 \mathrm{O}+$ and e-. In the next reaction free radicals are formed which then combine with peroxide. If peroxide and free radicals react with other molecules, compounds will be formed that will affect the plant biology system (Van Harten, 1998).

\section{Leaf color}

Observation of the appearance of leaf color is a descriptive observation by looking at the color changes in the leaves if there is a change in the effect of the mutation.

Based on observations in the field after Gammacell 220 (Cobalt-60) light bulb irradiation was found there was a difference in leaf color at the age of 16 MST. Picture of leaf color can be seen in table 3.

The treatment that has been done shows the difference in leaf color at 30 gray, 90 gray and 0 gray. At 0 gray shows the normal leaf shape where the leaf is a solid green color and the type of leaf color is a common type in white taro, 30 gray shows a slightly yellowish green leaf shape where the yellow color is visible on the edges of the leaf, 90 gray shows the dominant white green leaf color shape, while 60 and 120 gray shows the same leaf color at 0 gray.

Mutation is a process in which genes undergo changes or all types of changes in hereditary material that cause phenotypic changes inherited from one generation to the next. Research conducted by Royani (2012), induction of physical mutations with gamma ray irradiation has influenced changes in the morphological character of sambiloto plants, especially on leaves. Grosch and Hapwood (1979) add that irradiation in plants can cause different leaf shapes including growth inhibition (dwarf), fusion of leaves, and mosaic (change in color).

In this study, there was an expression of taro leaves from mutations in chloroplast DNA (cp DNA) which resulted in less plastide in some tissues or could not produce chlorophyll, while others produced normal chlorophyll, so the leaves were partly green and white or yellow. Changes in the character of chloroplasts can affect the biosynthesis of curcumin. Heldt (1997) states that leaves can absorb nitrogen in the form of nitrates, then chloroplasts change it in the form of ammonium and then become phenylalanine amino acids through a cyclic path. Markham (1998) adds that these amino acids are precursor amino acids for the phenylpropanoid pathway in flavonoid biosynthesis. Curcumin is a type of flavonoid secondary metabolite. Research conducted by Ling et al. (2008) in the form of gamma ray irradiation on the Citrus sinensis plantlets resulting in an increase in protein content, but the resulting chlorophyll content was not higher compared to plantlets without irradiation. In general, changes in the genetic structure will cause changes in their expression (protein form). These changes continue to cause changes in metabolism.

Physiological damage is also able to change metabolism without any changes in genetic material. Metabolic changes will cause changes in chemical content (proteins, enzymes, metabolites), morphological changes (shape and color), changes in adaptability (due to changes in morphology and metabolism), and conditional mutants.

\section{Plant height}

Plant height measurement is done by measuring the height of each plant from the end of the standard pole to the longest leaf tip, observations made using a meter. Plant height data can be seen in table 2 .

Based on observations of plant height showed that high doses (gray) greatly affect the height of the taro plant, the higher the dose (gray) is given the lower the height of the taro plant.

A high decrease in plants or plants becomes stunted due to the influence of high doses due to physiological disorders or chromosomal damage caused by mutagen (gamma ray radiation) given. Gamma rays belong to pegionic radiation and interact with atoms or molecules to produce free radicals (losing one electron from the free electron pair) in the cell. These radicals can damage or modify very important components in plant cells and cause a partial change of morphology, anatomy, biochemistry and plant physiology depending on the level of radiation. This shows that mutation breeding can create genetic diversity in quantitative characters (Al Safadi et al., 2009). Taro plant height after Gammacell 220 cobalt(60) ray irradiation can be seen in Figure 3 below.

Adding doses of gamma radiation causes a decrease in plant height. Allegedly caused by gamma rays that damage the plant chromosome composition, so that it affects the growth of plants. This is in accordance with the statement of Ritonga and Wulansari (2010), namely the higher the radiation dose, the lower the plant height; the decrease in plant height occurs because irradiation can damage the plant chromosomes, resulting in disruption of the plant. 


\section{FIGURES AND TABLES}

Table.1: Data on the calculation of Ld 50 (lethal dose 50) in taro plants aged $4 \mathrm{MST}$

\begin{tabular}{cccccc}
\hline \multicolumn{5}{c}{ Gammacell } & \multicolumn{6}{c}{ (Cobalt-60) } & ray & irradiation & rate \\
\hline Gray & $\begin{array}{c}0 \\
\text { (gray) }\end{array}$ & $\begin{array}{c}30 \\
\text { (gray) }\end{array}$ & $\begin{array}{c}60 \\
\text { (gray) }\end{array}$ & $\begin{array}{c}90 \\
\text { (gray) }\end{array}$ & $\begin{array}{c}120 \\
\text { (gray) }\end{array}$ \\
\hline $\begin{array}{c}\text { Value } \\
\text { Ld 50 \% }\end{array}$ & 4 & 25,23 & 54,98 & 81,75 & 123,87 \\
\hline
\end{tabular}

Table.2: High yield data on taro plants aged $16 \mathrm{MST}$.

\begin{tabular}{rrrrr} 
Gammacell & 220 (Cobalt-60) & ray irradiation rate \\
\hline 0 & 30 & 60 & 90 & 120
\end{tabular}

\begin{tabular}{cccccc} 
Gray & (gray) & (gray) & (gray) & (gray) & (gray) \\
\hline $\begin{array}{c}\text { Plant } \\
\text { height } \\
(\mathrm{cm})\end{array}$ & 50,04 & 33,8 & 33,92 & 36,7 & 30,16 \\
\hline
\end{tabular}

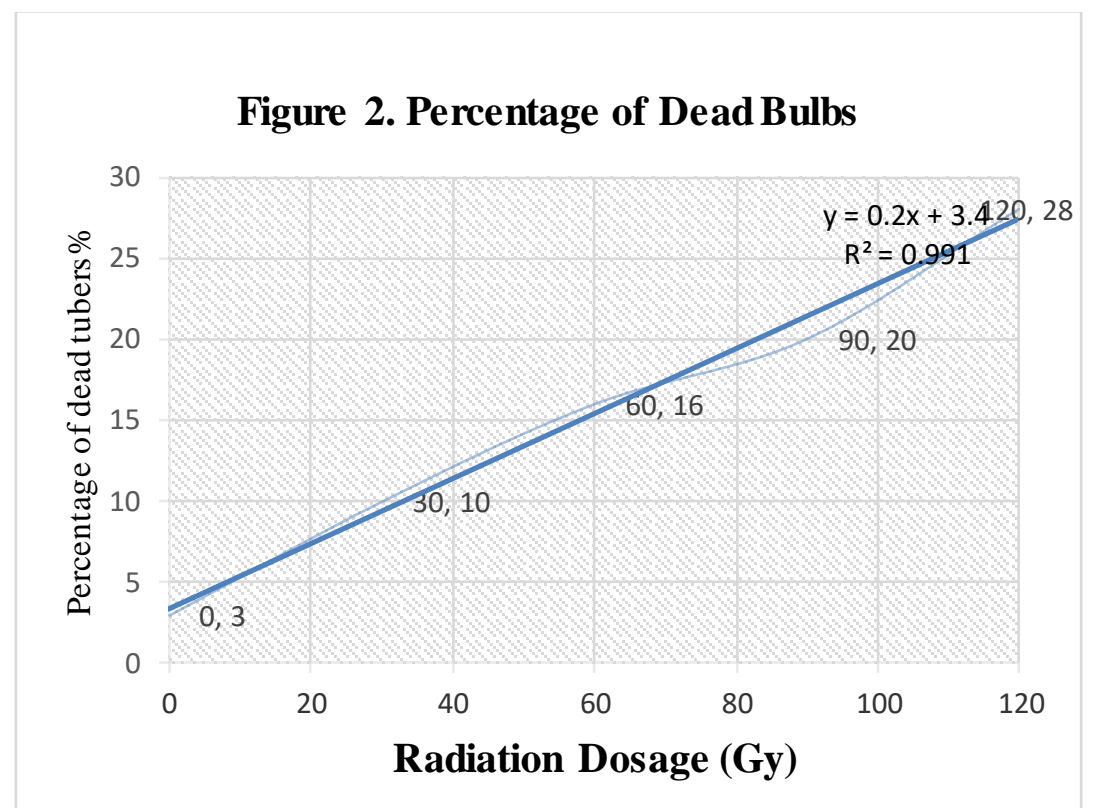

Fig.2: Percentage of dead tubers after being treated with Gammacell 220 cobalt-(60) ray irradiation, namely: 0 Gy, 30 Gy, $60 \mathrm{~Gy}, 90 \mathrm{~Gy}$ and $120 \mathrm{~Gy}$.
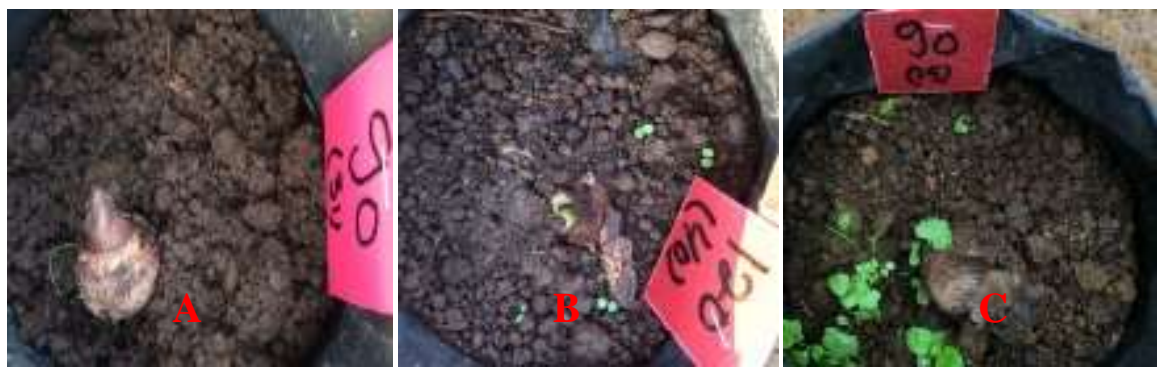

Fig.1: Taro plant tubers, A: burnt tuber skin, B: rotten bulb eye, C: rotten tubers

Table 3. Display of leaf color at age 16 MST.

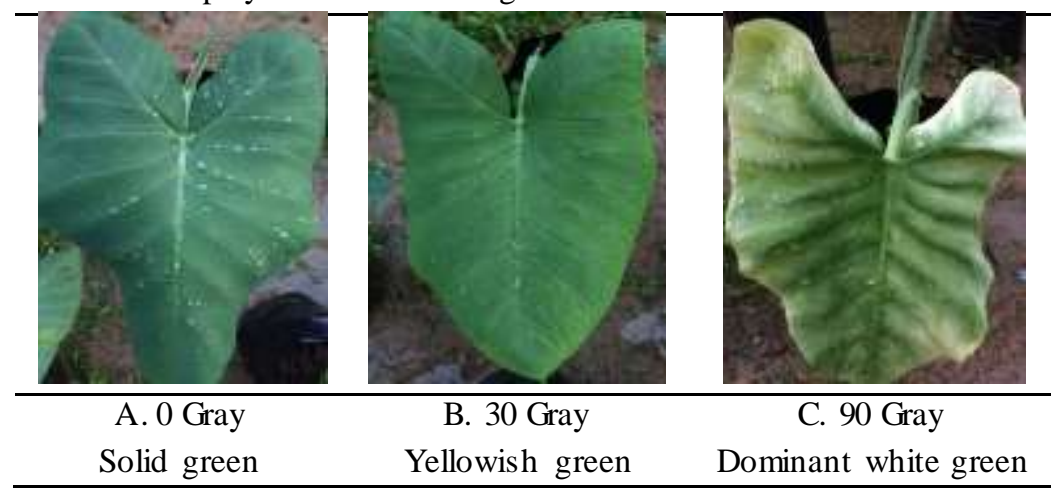




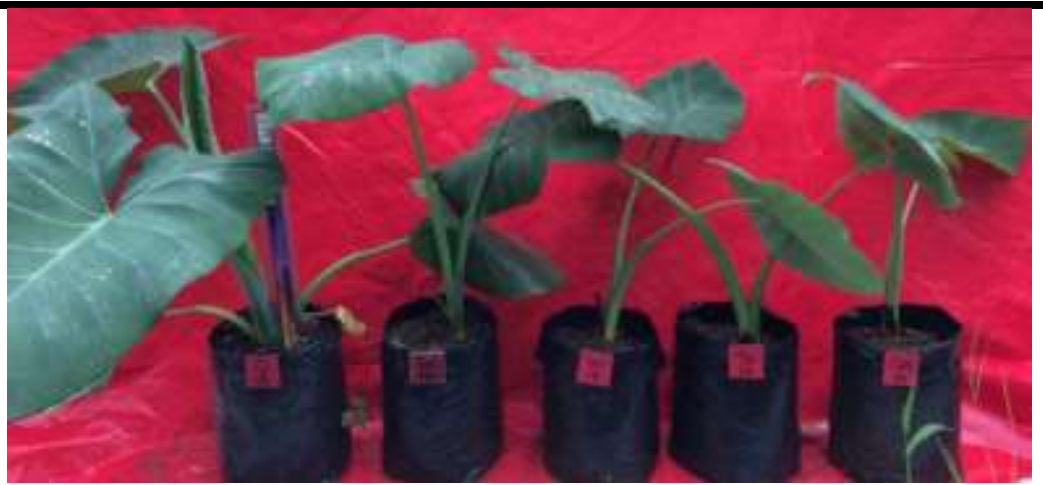

Fig.3: Height of taro plants, 0 gray, 30 gray, 60 gray, 90 gray and 120 gray.

\section{CONCLUSION}

Based on the results of the research that has been done it can be concluded that the value of Ld 50 (Lethal dose 50), at the level of Gammacell 220 (Cobalt-60) light irradiation occurs in 60 gray, leaf color variations only occur at irradiation levels of 30 and 90 gray while for plant height occurs at all levels of irradiation.It is recommended that further research be carried out regarding the content of calcium oxalate and proximate acid

\section{ACKNOWLEDGMENT}

Thanks to the Professor Research Cluster Scheme chaired by Prof. Dr. Ir. Zulfadly Syarif, MP with No: 40 / UN / 16.17 / PP.RGBL / LPPM / 2018 who have participated in the research.

\section{REFERENCES}

[1] Aisyah, S. I. 2006. Induction mutations, p. 159 - 178. In S. Sastrosumarjo (Ed.) Plant Cytogenetics. IPB Press. Bogor..

[2] Arifin Z, 2015. The development of taro plants is a leading commodity on community land in Pegantenan District, Pamekasan Regency. Journal of Agrovigor Volume 8 No. 2 September 2015 ISSN 19795777.

[3] Bryan A, W, Gayatri C, Frenly W. 2014. Potential of taro tuber starch extract (Colocasia Esculenta (L)) as an alternative source of starch in Indonesia. Pharmaceutical Scientific Journal. UNSRAT Vol. 3 No. August 3, 2014 ISSN. Pages: 2302-2493.

[4] Gehring, R. 1985. The effect of gamma radiation on salix nigra marsh. Cuttings. Arkansas Academy of Science Proceedings 39. Page:40-43.

[5] Grosch, D.S., L.E. Hapwood. 1979. Biological Affects of Radiations. Ed ke-2. Academic Pr. New York (US).

[6] Hafsah, Topik H, Kusdianti, 2014. The phenetic relationship among taro cultivar (Colocasia esculenta (L)) based on vegetative morphological characters. Jurnal Bioslogos, Februari 2014, Vol. 4 Nomor 1.

[7] Herison, C., Rustikawati, Sujono H. S., Syarifah I. A. 2008. Induction of mutations through gamma rays against seeds to increase the diversity of the basic population of maize (Zea mays L.). Agrosia Act 11 (1): 57-62.

[8] Kim, J.H., M.H. Bae K., B.Y. Chung, S.G. Wi, and J.S. Kim. 2004. Alterations in the photosynthetic pigments and antioxidant machineries of red pepper (Capsicum annum L.) seedlings from gammairradiated seeds. J. Plant Biol. 47:314-321.

[9] Kovacs E, Keresztes A. 2002. Effect of gamma and $U V B / C$ radiation on plantcell. Micron. 33:199-210.

[10] PPIN BATAN. $2008 . \quad$ Radiation. http://www.batan.go.id/FAQ/faq_radiasi.php. [31 Oktober 2009]

[11] Royani, J.I. 2012. Effect of 60Co gamma ray irradiation on changes in morphological, molecular character, active compounds of bitter plant (Andrographis paniculata). Essay. Bogor Agricultural Institute. Bogor.

[12] Rudyatmi E, Enni S,R, 2014. Central Java local taro characterization (identification of germplasm sources as an alternative food conservation effort). Department of Biology, Faculty of Mathematics and Natural Sciences, Semarang State University. Vol. 12 No.1 July 2014.

[13] Soeranto, H. 2012. Utilization of nuclear technology for sorghum breeding. Workshop on the Current Status and Challenges in Sorghum Development in Indonesia. Seameo Biotrop. Bogor, September 25-26 2012.120 p.

[14] Sudomo A, Aditya H. 2014. Taro productivity (Colocasia esculenta (L). Schott) is below three types of stands with agroforestry systems on community forest lands. Journal of Forestry Science, Volume 8 No. 2 July-September 2014. Research Center for Agroforestry Technology Ciamis. 
[15] Sundari D F. Albiner S. Jumirah, 2014. Measurement of glycemic index value of belitung taro flour cookies (Xanthosoma sagittifolium (L)). FKM USU

[16] Thomson, Weil C S, 1952. Tables for convenient calculation of median effective dose (Ld50 or Ed50) and instructionsin their use. Biometrics 8. Page:249263.

[17] Van Harten, A.M. 1998. Mutation Breeding. Theory and Practical Aplication. Cambridge University Press. NewYork, USA. p. 342. 